\title{
THE EFFECT OF LIVE YEAST (Saccharomyces cerevisiae) ON MILK YIELD OF CROSSBRED DAIRY CATTLE AT KHUMALTAR, NEPAL
}

\author{
B. Acharya ${ }^{1 *}$ and B. Dhital ${ }^{2}$ \\ ${ }^{1}$ Faculty of Agriculture Science, Farwestern University, Tikapur, Nepal \\ ${ }^{2}$ Directorate of Research and Publication, Institute of Agriculture and Animal Science, \\ Tribhuvan University, Nepal \\ *basantacharya@gmail.com
}

\begin{abstract}
A study was carried out to assess the effect of live yeast Saccharomyces cerevisiae (Nutriferm ${ }^{\mathrm{TM}}$ ) on milk production at National Cattle Research Program Khumaltar Lalitpur from 19 March 2015 to 15 April 2015. Twenty crossbred cattle were selected randomly and divided into five treatment groups. Each group had four animals arranged in Complete Randomized Design (CRD). Among five treatment groups, treatment $\left(\mathrm{T}_{1}\right)$ was treated with $0.5 \mathrm{~kg} / \mathrm{MT}$ of live yeast Saccharomyces cerevisiae (SC) incorporated feed, treatment $\left(\mathrm{T}_{2}\right)$ with $1 \mathrm{~kg} / \mathrm{MT} \mathrm{SC}$, treatment $\left(\mathrm{T}_{3}\right)$ with $1.5 \mathrm{~kg} / \mathrm{MT} \mathrm{SC}$, treatment $\left(\mathrm{T}_{4}\right)$ with $2 \mathrm{~kg} / \mathrm{MT} \mathrm{SC}$ and treatment $\left(\mathrm{T}_{5}\right)$ as control without any live yeast inclusion in feed. Supplementation of the live yeast up to seventh day of the trial had statistically non-significant $(\mathrm{P}>0.05)$ effect on average milk yield per cattle between the treatments. Response of the yeast on mean milk yield per cattle between the treatments was found statistically different $(\mathrm{P}<0.05)$ on fourteenth day and twenty-eight day of the trial. On fourteenth day mean milk yield of control group $\left(\mathrm{T}_{4}\right)$ was statistically significant with highest dose rate inclusion $\mathrm{T}_{4}$ only but remained non-significant with the rest of the lower dose rate treatments. With further supplementation of the yeast up to $28^{\text {th }}$ day of the trial results showed the statistically significant effect with lower dose rate $T_{2}$ as well with respect to control group besides $\mathrm{T}_{4}$. Hence, the result of this experiment indicates that supplementation of live yeast for at least 14 days has role in the enhancement of milk production in crossbred dairy cattle with faster effect by dose rate of $\mathrm{T}_{4}$ treatment.
\end{abstract}

Key Words: Saccharomyces cerevisiae, milk yield, crossbred cattle

\section{INTRODUCTION}

Nepal has an emerging economy and its income is primarily based on agriculture. Agriculture sector contributes about 32.61 percentages in Gross Domestic Product (GDP) and supports about 65.6 percentage of the population in our country (MOAD, 2014). Agriculture in Nepal is a way of sustaining life and multi species livestock sector plays significant role in agricultural development and economic empowerment of the country. It contributes 31 percentages in the National Agricultural Gross Domestic Product (AGDP) (CBS, 2012). Livestock sector of Nepal is broadly characterized by large number of animals with low level of productivity (TLDP, 2002). Livestock have been playing vital role in rural economy but level of income from this sector is comparatively low due to low productivity of the animals (CBS, 2002). Milk production from cattle and buffalo is one of the important sub sectors in Nepalese economy. In Nepal, the total milk production is around 18,54,247 MT per year where dairy cattle and buffalo produce around 6,43,806 and 12,10,441 MT of milk respectively (MoAD, 2015/016). Out of the total annual milk production of 18,54,247 MT, dairy cattle contribution is 34.72 percentage. The population of dairy cattle and buffalo are estimated to be $73,02,808$ and 51,68,809 respectively (MOAD, 2015/16). Dairy industry contributes a big share on livestock sector but growth of milk production over last decade has been insignificant i.e. only 2.6 
percentage per year (Pradhan et al., 2003). Milk processing industries have spent more than 237.3 million Rupees to import dairy products only from India (MOAD, 2014).

With the purpose of enhancing milk production, scientists over the last couple of decades have been attempting to manipulate the microbial activities in ruminants. Nowadays, chemical feed additives are considered as common means to enhance milk production. The mode of action of these additives varies according to the ruminal fermentation patterns. Some other feed additives, antibiotics and ionophores have antimicrobial activities which enable them to eliminate specific harmful organisms present in the rumen. The use of feed additives like antibiotics are not safe stimulants due to the possibility of various chemicals entering the food chain of human (Chiquette, 1995) and at the same time there is high incidence of increasing residual effects of antibiotics additives including hormones. Many researchers have shown beneficial results with the inclusion of live yeast cultures in ration of lactating dairy cattle. The low manufacturing costs associated with the production of yeast cultures have enhanced their use. In contrast to chemical feed additives, yeast cultures stimulate and enhance multiplication of cellulolytic bacteria in rumen, which has resulted alternative use of yeast as a natural, safe and cost-effective feed additive (Newbold et al., 1992). Yeast has been utilized successfully for many years in animal feed industries. In feed industry; antimicrobials, natural products and yeast are used as probiotics and growth promoters (Muihead, 1992).

Due to fungal origin, yeast and its derivatives have resistant property to anti-bacterial agents (Auclair, 2000). Live yeast (Saccharomyces cerevisiae) culture is a fermented feed additive product (Linn \& Raeth-Knight, 2006). Live yeast extract improves the feed efficiency and milk yield as it is a source of naturally occurring B-vitamins and disaccharides enzymes which enhance digestion of fiber, protein, fats and minerals (Buts et al., 1994). Specifically, live Yeast extract (Saccharomyces cerevisiae) has capability to competitively inhibit pathogenic bacteria and to promote growth of beneficial bacteria (Gedek, 1989). Therefore, this study was conducted to find out the impact of live yeast (Saccharomyces cerevisiae) on milk yield of crossbred cattle.

\section{MATERIALS AND METHODS}

\section{Research design}

The experiment was conducted by using Complete Randomized Design (CRD). Total of 20 crossbred cattle were randomly allocated in five different treatments with four replications each cattle representing an experimental unit. Efforts were made to group cattle with similar parity and age into a treatment group. The cattle were under study for 12 to 40 days after parturition. The five different dietary treatment groups $\mathrm{T}_{1}, \mathrm{~T}_{2}, \mathrm{~T}_{3}, \mathrm{~T}_{4}$ and $\mathrm{T}_{5}$ are as follows.

$\mathrm{T}_{1}=$ Concentrates enriched with live yeast (S. cerevisiae) @ $0.5 \mathrm{~kg} / \mathrm{MT}$ of feed and rice straw and green oat.

$\mathrm{T}_{2}=$ Concentrates feed enriched with live yeast (S. cerevisiae) @ $1 \mathrm{~kg} / \mathrm{MT}$ of feed and rice straw and green oat.

$\mathrm{T}_{3}=$ Concentrates feed enriched with live yeast $(S$. cerevisiae) @ $1.5 \mathrm{~kg} / \mathrm{MT}$ of feed and rice straw and green oat.

$\mathrm{T}_{4}=$ Concentrates feed enriched with live yeast (S. cerevisiae) @ $2 \mathrm{~kg} / \mathrm{MT}$ of feed and rice straw and green oat.

$\mathrm{T}_{5}=$ Normal concentrates feed and normal rice straw and green oat. 
Table 1: Tag no. of cattle in experiment

\begin{tabular}{ccccc}
\hline Dietary treatment & Block 1 & Block 2 & Block 3 & Block 4 \\
\hline $\mathbf{T}_{\mathbf{1}}$ & 1806 & 1725 & 1681 & 1570 \\
$\mathbf{T}_{\mathbf{2}}$ & 1750 & 1767 & 1683 & 1644 \\
$\mathbf{T}_{\mathbf{3}}$ & 1808 & 1781 & 1687 & 1530 \\
$\mathbf{T}_{\mathbf{4}}$ & 1752 & 1763 & 1685 & 1539 \\
$\mathbf{T}_{\mathbf{5}}$ & 1798 & 1713 & 1629 & 1639 \\
\hline
\end{tabular}

\section{Preparation of the experimental cattle feed}

Cattle feed used in this experiment was manufactured by Proboitech Industry Pvt. Ltd., Parsa Nepal and was incorporated live yeast supplement S. cerevisiae (Nutriferm $\left.{ }^{\mathrm{TM}}\right)$. These cattle ration were adequately fortified with minerals and vitamin premixes too. Major raw ingredients used to manufacture pellet cattle feed are as mentioned:

Table 2: Ingredients used for preparation of cattle feed

\begin{tabular}{lc}
\hline Ingredients & Percentage \\
\hline Maize & 20 \\
Soybean Meal & 5 \\
De-oiled Rice Bran & 50 \\
De-oiled Mustard oil cake & 15 \\
Molasses & 7 \\
Vitamin and mineral premix & 3 \\
\hline Total & $\mathbf{1 0 0}$ \\
\hline
\end{tabular}

\section{Nutrients analysis}

The proximate nutrient constituent analysis of the samples of all treatments was determined three times covering the entire experimental period. Moisture, crude protein $(\mathrm{CP})$, crude fiber $(\mathrm{CF})$, ether extracts (EE), total ash, sand silica, calcium and phosphorous were analyzed at Animal Nutrition Laboratory of Probiotech Industry Pvt. Ltd., Parsa using the methods described in AOAC (1997).

Table 3: Nutrients composition of cattle feed

\begin{tabular}{cllcccc}
\hline S.N. & Parameters & $\mathbf{T}_{1}$ & $\mathbf{T}_{2}$ & $\mathbf{T}_{3}$ & $\mathbf{T}_{4}$ & $\mathbf{T}_{5}$ \\
\hline 1 & Moisture (\%) & 9.62 & 10.52 & 10.23 & 10.97 & 10.09 \\
2 & Total Ash (\%) & 9.38 & 9.37 & 9.42 & 9.42 & 9.47 \\
3 & Sand Silica (\%) & 2.44 & 2.43 & 2.38 & 2.53 & 2.55 \\
4 & Fat content (\%) & 2.43 & 2.52 & 2.5 & 2.49 & 2.58 \\
5 & Crude Fiber (\%) & 6.01 & 6.04 & 6.31 & 6.37 & 6.21 \\
6 & Crude Protein (\%) & 21.95 & 22.25 & 21.13 & 21.3 & 22.13 \\
7 & Calcium (\%) & 0.62 & 0.62 & 0.7 & 0.65 & 0.71 \\
8 & Phosphorous (\%) & 0.66 & 0.69 & 0.69 & 0.69 & 0.67 \\
\hline
\end{tabular}

\section{Daily milk yield in liter}

Total data of 28 days of milk yield was collected. The daily milk yield (liter) was recorded directly in farm of National Cattle Research Program Khumaltar, Lalitpur. 


\section{Statistical analysis}

The observed data was tabulated in Ms-Excel and transferred to SPSS 16 version data sheet. Test statistic for the mean differences in the milk yield for different treatments was analyzed with repeated measures Analysis of Variance (ANOVA) by General Linear Model. Bonferroni Pair wise multiple comparisons were done for the interaction effects of time with treatments groups.

\section{RESULT AND DISCUSSION}

The effects of live yeast (Saccharomyces cerevisiae) on milk production among different treatment groups are included in the study. The data is compared for the effects of live yeast (Saccharomyces cerevisiae) on milk yield among different treatment groups across different time points of feeding.

Mean milk yield per cattle per day were significantly different between treatments at $\mathrm{P}<0.05$ across different time points. Mean milk yield per cattle per day comparison on the first day of the trial to $7^{\text {th }}$ day of the trial were statistically non-significant $(\mathrm{P}>0.05)$ between the treatments. But the results showed significant effect $(\mathrm{P}<0.05)$ on milk yield by the $14^{\text {th }}$ day of yeast feeding with $\mathrm{T}_{4}$ group only with respect to control $\left(T_{5}\right)$ and rest of the treatments $T_{1}, T_{2}, T_{3}$ were insignificant with control $\left(\mathrm{T}_{5}\right)$. Also the group $\mathrm{T}_{4}$ was statistically non-significant $(\mathrm{P}>0.05)$ among $\mathrm{T}_{1}, \mathrm{~T}_{2}$ and $\mathrm{T}_{3}$ on $14^{\text {th }}$ day. This suggest that there is no significant effect upon milk yield up to $7^{\text {th }}$ day of yeast feeding in all dose rate of the treatments with respect to control but has effect of dose rate $2 \mathrm{~kg} /$ ton by the $14^{\text {th }}$ day of yeast feeding with highest milk yield $15.37 \pm 1.79$ liters per cattle per day followed by $\mathrm{T}_{2}, \mathrm{~T}_{3}, \mathrm{~T}_{1}$ and $\mathrm{T}_{5}$ as shown in the table 4 below. However, the effect was non-significant by the $21^{\text {st }}$ day of yeast feeding and again there were significant effect of yeast feeding in milk production on $28^{\text {th }}$ day with $\mathrm{T}_{4}(15.45 \pm 1.97)$ with respect to the control group, moreover mean milk yield $(14.57 \pm 2.15)$ of $\mathrm{T}_{2}$ was also statistically found to be different with respect control. These suggest that lower dose rate yeast inclusion also had relatively slower effect upon enhanced milk yield than non-inclusion of yeast in feed.

Table 4: Mean \pm SEM milk yield at a week apart

\begin{tabular}{lccccc}
\hline \multicolumn{6}{c}{ Milk yield in Kg (Mean \pm SEM) } \\
\hline Treatments & $\mathbf{1}^{\text {st }}$ Day & ${7^{\text {th }}}^{\text {Day }}$ & $\mathbf{1 4}^{\text {th }}$ Day & $\mathbf{2 1}^{\text {st }}$ Day & $\mathbf{2 8}^{\text {th }}$ Day \\
\hline $\mathrm{T}_{1}(\mathrm{SC} 0.5 \mathrm{~kg} / \mathrm{MT})$ & $9.25 \pm 1.19 \mathrm{a}$ & $10.97 \pm 1.72 \mathrm{a}$ & $11.77 \pm 1.25^{\text {ab }}$ & $12.23 \pm 1.76 \mathrm{a}$ & $12.60 \pm 1.18^{\text {ab }}$ \\
$\mathrm{T}_{2}(\mathrm{SC} 1 \mathrm{~kg} / \mathrm{MT})$ & $12.00 \pm 3.02 \mathrm{a}$ & $12.96 \pm 2.22 \mathrm{a}$ & $14.38 \pm 2.32^{\text {ab }}$ & $13.15 \pm 2.24 \mathrm{a}$ & $14.57 \pm 2.15^{\text {ac }}$ \\
$\mathrm{T}_{3}(\mathrm{SC} 1.5 \mathrm{~kg} / \mathrm{MT})$ & $11.50 \pm 2.35 \mathrm{a}$ & $11.99 \pm 2.44 \mathrm{a}$ & $12.04 \pm 2.25^{\text {ab }}$ & $12.77 \pm 2.42 \mathrm{a}$ & $11.95 \pm 1.73^{\text {ab }}$ \\
$\mathrm{T}_{4}(\mathrm{SC} 2 \mathrm{~kg} / \mathrm{MT})$ & $14.08 \pm 1.20 \mathrm{a}$ & $15.31 \pm 2.01 \mathrm{a}$ & $15.37 \pm 1.79 \mathrm{a}$ & $14.77 \pm 1.72 \mathrm{a}$ & $15.45 \pm 1.97^{\mathrm{a}}$ \\
$\mathrm{T}_{5}(\mathrm{SC} 0 \mathrm{~kg} / \mathrm{MT})$ & $6.90 \pm 0.54 \mathrm{a}$ & $6.53 \pm 0.71 \mathrm{a}$ & $6.69 \pm 0.60 \mathrm{~b}$ & $7.17 \pm 0.63 \mathrm{a}$ & $6.07 \pm 0.39^{\mathrm{b}}$ \\
\hline
\end{tabular}

Note: Means with different superscripts are statistically different at 0.05 level of significance

Mean milk yield was significantly different across different time points between treatments. The various results of milk yield during the experiment are compared with other similar researches which were conducted in different area in different time periods by different scientists. The results are discussed for possible interpretation, justification and analysis added by possible cause and literature support. The data are compared for the effects of live yeast (Saccharomyces cerevisiae) on milk production among different treatment groups. 
In different researches, increased in milk production was due to the increased proportion of propionic acid in total volatile fatty acid profile which resulted into increased number of essential microbes in the rumen (Weidmeier et al., 1987; Harrison et al., 1988; Dawson, 1990; Newbold et al., 1992; Dawson 1993). This result was in accordance with the result of Williams et al. (1991) who also observed increment in milk yield by 1.4 liters per day when yeast culture (Saccharomyces cerevisiae) was fed to dairy cattle. It was reported that supplementation with Saccharomyces cerevisiae in the cattle feed improved feed intake (Poppy et al., 2012), milk production (Nocek et al., 2011), digestion of nutrients (Miller-Miller-Webster et al., 2002) and concentration of volatile fatty acids in rumen (Arcos-Garcia et al., 2000).

Addition of Saccharomyces cerevisiae in cattle feed increased dry matter intake because of increased number of anaerobe and cellulolytic bacteria and increased digestibility of nutrients. Promkot et al., (2013) also reported that the effect of Saccharomyces cerevisiae, which was added in cattle feed had a higher rate of milk yield and quicker result as compared to the control group. Various scientific studies proved that, supplementation of Saccharomyces cerevisiae in cattle feed increased milk yield (Nocek et al., 2003; Nocek and Kautz, 2006; Al-Ibrahim et al., 2010; Bruno et al., 2009; Nocek et al., 2011). According to Maamouri et al., (2014) significant result of milk yield as well as milk fat and protein percentage was obtained when cattle were fed live yeast (Saccharomyces cerevisiae) supplemented feed. Bruno et al. (2009) also reported that cattle fed with supplemented live yeast (Saccharomyces cerevisiae) produced $1.2 \mathrm{~kg} /$ day more milk as compared to control and similar results were observed by Williams et al. (1991), Wohlt et al. (1991), Piva et al. (1993) and Dutta et al. (2008).

But some authors observed contradictory results that, there was non-significant response on milk yield when live yeast (Saccharomyces cerevisiae) was incorporated in cattle feed (Erdman and Sharma, 1989; Arambel \& Kent, 1990; Swartz et al., 1994). Similarly Kung et al. (1997) also found no any significant result in his study on milk production, milk composition and dry matter intake of cattle which were fed with live yeast (Saccharomyces cerevisiae) on malt extract agar in their ration. Likewise, effect of live yeast (Saccharomyces cerevisiae) on cattle feed had nonsignificant change in milk production, dry matter intake, body weight gain, milk yield and milk composition (Kamalamma et al., 1996). In some experiments, researchers did not find remarkable improvement on milk yield in dairy cattle when live yeast (Saccharomyces cerevisiae) was used in cattle feed (Adams et al., 1981; Weidmeier et al., 1987; Erdman \& Sharma, 1989; Arambel \& Kent, 1990; Chademana \& Offer, 1990; Nicholasville et al., 1994; Dann et al., 2000; Kalmus et al., 2009; Promkot et al., 2013). Some other scientific studies also showed that the supplementation of Saccharomyces cerevisiae had no any visible effect on milk production as well as on composition of milk in dairy cattle (Dann et al., 2000; Kalmus et al., 2009; Al-Ibrahim et al., 2010; Promkot et al., 2013).

According to Putman et al. (1997) milk yield of dairy cattle increased with the addition of Saccharomyces cerevisiae only when protein content was deficient in the diet of ruminant. There was no consistency among the results of the experiments in which Saccharomyces cerevisiae was supplemented. This situation might have resulted due to the use of various doses in experiment, stage of lactation and animal age, composition of feed and feeding strategy. It has been stated that Saccharomyces cerevisiae is more effective in the diets in which nutrient content is inefficient or in high energy diets (Masek et al., 2008). So, this result of study suggests that effect of live yeast is reflected on milk production by second week onwards and suggests that effect is seen in lower level of yeast inclusion after $28^{\text {th }}$ day onwards only. 


\section{CONCLUSION}

This experiment indicates that supplementation of live yeast for at least 14 days has role in the enhancement of milk production in crossbred dairy cattle. Farmers will enjoy the benefit of getting higher milk production of yeast feeding with faster effect of live yeast at the inclusion rate of $2 \mathrm{~kg} /$ MT in their concentrates whereas lower inclusion rate $1 \mathrm{~kg} /$ ton also had slower response to enhance the milk yield per cattle per day.

\section{ACKNOWLEDGEMENT}

The authors express deep sense of gratitude to National Cattle Research Program, NARC for providing the farm facilities available for this study and Probiotech Industry Pvt. Ltd. for providing feed and laboratory support needed for experiment.

\section{REFERENCES CITED}

Adams, D. C., Galyean, M. L., Kiesling, H. E., Wallace, J. D. \& Finkner, M. D. (1981). Influence of viable yeast culture, sodium bicarbonate and monensin on liquid dilution rate, rumen fermentation and feedlot performance of growing steers, and digestibility in lambs. Journal of Animal Science, 53,780-789.

Al-Ibrahim, R. M., Kelly, A.K., O'Grady, L., Gath, V. P., McCamey, C., \& Mulligan, F.J. (2010). Effect of body condition score at calving and supplementation with Saccharomyces cerevisiae on milk production, metabolic status and rumen fermentation of dairy cattle in early lactation. Journal of Dairy Science, 93, 5318-5328.

Arambel, M. J., \& Kent, B.A. (1990). Effect of yeast culture on nutrient digestibility and milk yield response in early to mid-lactation dairy cows. Journal of Dairy Science, 73, 1560-15.

Arcos-Garcia, J. L., Castrejon, F. A., Mendoza, G. D. \& Perez-Gavilan, E.P. (2000). Effect of two commercial yeast cultures with Saccharomyces cerevisiae on ruminal fermentation and digestion in sheep fed sugar cane tops. Journal of Livestock Production Science, 63, 153157.

Auclair, E. (2000). Yeast as an examples of the mode of action of probiotics in monogastric and ruminant species. Lesaffre Dèvelopment, 147 rue G. Prei, BP 6027, 59706 Marcq en Baroeul Cedex, France.

Bruno, R. G. S., Rutiglianoa, H. M., Cerric, R. L.,Robinsonb, P. H., \& Santos, J. E. P. (2009). Effect of feeding Saccharomyces cerevisiae on performance of dairy cows during summer heat stress. Journals of Animal Feed Science Technology, 150, 175-186.

Buts, J. P., De. Keyser, N., \& De. Reademaeker, L . (1994). Saccharomyces boulardii enhance rat intestinal enzymes expression by endoluminal release of polyamines. Pediatr. Res. 36, 522527.

CBS. (2002). Statistical pocket book. National Planning Commission Secretariat, Central Bureau of Statistics, Kathmandu, Nepal.

CBS. (2012). Statistical pocket book. National Planning Commission Secretariat, Central Bureau of Statistics, Kathmandu, Nepal.

Chademana, I., \& Offer, N. W. (1990). Effect of dietary inclusion of yeast culture on digestion in the sheep. Journal of Animal Production, 50, 483-489.

Chiquette, J. (1995). Saccharomyces cerevisiae and Aspergillus oryzae used alone or in combination, as feed supplement for beef and dairy cattle. Canadian Journal of Animal Science, 75,405415. 
Dann, H. M., Drackley, J. K., McCoy, G. C., Hutjens, M. F., \& and Garrett, J. E. (2000). Effects of yeast culture (Saccharomyces cerevisiae) on pre-partum intake and postpartum intake and milk production of Jersey cows. Journal of Dairy Science, 83, 123-127.

Dawson, K.A. (1990). Designing the yeast culture of tomorrow: Mode of action of yeast culture for ruminants and non-ruminants in Biotechnology of Feed Industry. T.P. Lyons (Editor), Alltech Technical Publications, KY. Pp. 59-78.

Dawson, K. A. (1993). Current and future role of yeast in animal production: a review of research over the last seven years. T. P. Lyons, ed. Alltech Technical Publication. Pp 269.

Dutta, T.K., \& Kundu, S.S. (2008). Response of mixed viable probiotics culture on milk production and nutrient availability in crossbred mid-lactating cows. Indian Journal of Animal Science, 78, 531-535.

Erdman, R. A., \& Sharma, B.K. (1989). Effect of yeast culture and sodium bicarbonate on milk yield and composition in dairy cows. Journal of Dairy Science, 72, 1929-1932.

Gedek, B. (1989). Interaktion zwischeen lebden Hefezellen and darmpathogen Escheria- coli keimen. In: Okosystem Darm, Morphologic, Mikrobioloie, Immunologie, Müller, J., Ottenjann, R. and Seifert, J (eds). Springer Verlag, 135-139.

Harrison, G. A., Hemken, R. W., Dawson, K. A., \& Harmon, B.J. (1988). Influence of addition of yeast culture supplement to diets of lactating cows on ruminal fermentation and microbial populations. Journal of Dairy Science, 71, 2967-2875.

Kalmus, P., Orro, T., Waldmann, A., Lindjarv, R., \& Kask, K. (2009). Effect of yeast culture on milk production and metabolic and reproductive performance of early lactation dairy cows. Acta Veterinaria Scandinav ica, Vol. 51-10.1186/17, 51-0147-51-32.

Kamalamma, U., Krishnamoorthy, U., \& Krishnappa, P. (1996). Effect of feeding yeast culture (YeaSacc 1026) on rumen fermentation in vitro and production performance in crossbred dairy cows. Journals of Animal Feed Science Technology, 57, 247-256.

Kung, L. Jr., Kreck, E.M.,Tung, R.S., Hession, A.O., Sheperd, A.C., Cohen, M.A., Swain, H.E., \& Leddle, J.A.Z. (1997). Effects of a live yeast culture and enzymes on in vitro ruminal fermentation and milk production of dairy cows. Journal of Dairy Science, 80, 2045-2051.

Linn, J., \& Raeth-Knight, M.(2006). "Yeast in Dairy Cattle Diet" 2006 Four State Dairy Nutrition and Management Conference. 85-90.

Maamouri, O., Selmi, H., \& Hamdi, N.M. (2014). Effect of yeast (Saccharomyces cerevisiae) feed supplement on milk production and its composition in Tunisian Holstein Friesian cows. Scientia agriculturae bohemica. 45, 3 (Pp- 170-174).

Masek, T., Mikulec, Z., Valpotic, H.,Antunac, N., \& Mikulec, N. (2008). Influence of live yeast culture (Saccharomyces cerevisiae) on milk production and composition and blood biochemistry of grazing dairy ewes during the milking period. Acta Vet, 77, 547-554.

Miller-Webster, T., Hoover, W. H., Holt, M., \& Nocek, J. E. (2002). Influence of yeast culture on ruminal microbial metabolism in continuous culture. Journal of Dairy Science, 85, 20092014.

MOAD. (2015/016). Statistical information on Nepalese agriculture. Government of Nepal Ministry of Agriculture Development. Monitoring, Evaluation and Statistics Division. Agriculture Statistics Section. Singhdarbar Kathmandu Nepal.

MOAD. (2014). Statistical information on Nepalese agriculture. Government of Nepal Ministry of Agriculture Development. Agribusiness Promotion and Statistics Division. Singhdarbar Kathmandu Nepal. 
Muihead S. (1992). Direct- feed products. Direct feed microbial enzyme and forage additive compendium. The Miller Publishing Coy. Minnetonka. M. N. 45-207.

Newbold, C. J., Frumholtz, P. P., \& Wallace, R. J. (1992). Influence of Aspergillus oryzae fermentation extract on rumen fermentation and blood constituents in sheep given diets of grass hay and barley. Journal of Agriculture Science, 119, 423-427.

Nicholasville, K. Y., Swartz, D. L., Muller, L. D., Rogers, G. W., \& Varga, G. A. (1994). Effect of yeast cultures on performance of lactating dairy cows: a field study. Journal of Dairy Science, 77, 3073- 3080.

Nocek, J. E., Kautz, W. P., Leedle, J.A.Z., \& Block, E. (2003). Direct-fed microbial supplementation on the performance of dairy cattle during the transition period. Journal of Dairy Science, 86 , 331-335.

Nocek, J . E . \& Kautz, W. P. (2006). Direct- fed microbial supplementation on ruminal digestion, health and performance of pre and postpartum dairy Journal of Dairy Science, 89, 260-266.

Nocek, J.E., Holt, M. G., \& Oppy, J. (2011). Effects of supplementation with yeast culture and enzymatically hydrolyzed yeast on performance of early lactation dairy cattle. Journal of Dairy Science, 94, 4046-4056.

Piva, G., Belladonia, S., Fusconi, G. \& Sicbaldi, F. (1993). Effects of yeast on dairy cow performance, ruminal fermentation, blood components, and milk manufacturing properties. Journal of Dairy Science, 76, 2717-2722.

Poppy, G. D., Rabiee, A., Lean, I. J., Sanchez, W. K., Dorton, K. L., \& Morley, P. S. (2012). A meta-analysis of the effects of feeding yeast culture produced by anaerobic fermentation of Saccharomyces cerevisiae on milk production of lactating dairy cows. Journal of Dairy Science, 95, 602 7-6041.

Pradhan, D. R.,. Shrestha, H. R., \& Shrestha, R.G. (2003). Dairy technologies and their dissemination in Nepal.

Promkot, C., Wanapat, M., \& Mansathit, J. (2013). Effects of yeast fermented-cassava chip protein (YEFECAP) on dietary intake and milk production of Holstein crossbred heifers and cows during pre and post-partum period. Livestock Sci., 154, 112-116.

Swartz, D. L., Muller, L. D., Rogers, G. W., \& Varga, G.A. (1994). Effect of yeast cultures on performance of lactating dairy cows: a field study. Journal of Dairy Science, 77, 3073-3080.

TLDP. (2002). Forage seed production area mapping. Third Livestock Development Project, Harihar Bhawan, Lalitpur, Nepal.

Weidmeier, R. D., Arambel, M. J., \& Walters, J L. (1987). Effect of yeast culture and Aspergillus oryzae fermentation extract on ruminal characteristics and nutrient digestibility. Journal of Dairy Science, 70, 2063-2071. http://jds.fass.org/cgi/reprint/ 70/10/2063.pdf. (Retrieved on October 2015)

Williams, P. E. V., Tait, C. A. G., Innes, G. M., \& Newbold, C.J. (1991). Effects of the inclusion of yeast culture (Saccharomyces cerevisiae plus the growth medium) in the diet of dairy cows on milk yield and forage degradation and fermentation patterns in the rumen of steers. Journal of Animal Science 69, 3016-3026. http://www.journalofanimalscience.org/content/69/7/3016.

Wohlt, J. E., Finkelstein, A. D., \& Chung, C.H. (1991). Yeast culture to improve intake, nutrient digestibility, and performance by dairy cattle during early lactation. Journal of Dairy Science, 74,1395-1400. doi: 10.3168/jds.S0022-0302(91)78294-5. 